\title{
TRIMDINIEKA DZĪVES TĒLOJUMS ASTRĪDAS STANKES ROMĀNĀ HOW LONG IS EXILE?
}

Aija Priedīte, Dr. phil.

Tuvojoties Latvijas simtgadei, starp daudzajiem dažādu nozaru projektiem bija manāma rosība arī literatūrā. Līdztekus memuāriem un atmiņu literatūrai vēstures motīvi ieguva popularitāti arī daiḷliteratūrā, proti, romānos. Pretenciozākais projekts literatūras laukā noteikti bija Gundegas Repšes ideja, par ko varam lasīt:

2011. gadā, rakstnieces Gundegas Rep̌̌es iedvesmotas, divpadsmit latviešu rakstnieces kopīgi radīja stāstu krājumu Mēs. XX gadsimts - literāru versiju par 20. gs. Latviju. Šis stāstu krājums deva impulsu jau daudz plašākam projektam - Latvijas 20. gs. vēstures romānu sērijai Mēs. Latvija, XX gadsimts. Gundegas Repšes uzrunāti, kopīgā romānu sērijas radīšanā piedalīties piekrita trīspadsmit latviešu rakstnieki, uznemoties katrs savu nosacītu Latvijas 20. gs. vēstures periodu. Romānu sērijas kopējā vadlīnija ir rūpīga laikmeta dokumentu, liecību u. c. pieejamu avotu un materiālu izpēte, kas kalpo par pamatu katra individuālajam literārajam redzējumam, necenšoties to iegrožot. ${ }^{1}$

No 2013. līdz 2018. gadam ir iznākuši visi 13 sērijā paredzētie romāni², taču tikai daži no tiem pilda G. Repšes ieceri par kāda Latvijas vēsturiska perioda attēlošanu literatūrā. Līdztekus šai sērijai iznāk sērija Latvijas simtgades

1 Pieejams: https://www.goodreads.com/series/ 159041-m-s-latvija-xx-gadsimts (02.02.2018.).

2 Zebris, Osvalds Gaiḷ kalna ēnā; Berelis, Guntis Vārdiem nebija vietas; Bankovskis, Pauls 18; Gaile, Inga Stikli; Repše, Gundega Bogene; Bērziņš, Māris Svina garša; Ābele, Inga Duna; Ikstena, Nora Mātes piens; Kota, Laima Istaba; Manfelde, Andra Virsnieku sievas; Ulberga, Kristīne Tur; Jundze, Arno Sarkanais dzīvsudrabs; Akmentiňš, Andris Skolotāji. romāni, kura aptver Daces Judinas tetralogiiju ${ }^{3}$ par vairākām latviešu dzimtām attiecīgā laika vēsturiskajā kontekstā. Bez jebkādām pretenzijām vai norādēm uz romāna vēsturiskumu vienlaikus ar G. Repšes ierosināto romānu sēriju ASV iznāk Astrīdas Stankes (Stahnke) daudzus gadus rakstîtais romāns How Long is Exile? ${ }^{4}$ (Cik gara ir trimda?) angḷu valodā. A. Stankes romāna triloǵija aptver laiku no 20. gadsimta 30. gadiem līdz mūsu dienām un vietu Latvija-Vācija-ASV-Latvija. Lai gan trilogijas saturs balstās uz vienas galvenās personas, Mildas Bērziṇas-Arājas-Vanagas, dzīvi, tas aptver ḷoti plašu latviešu tautas piedzīvojumu atspoguḷojumu un Latvijas vēstures dalı.

A. Stanke izvadā lasītāju pa Mildas jaukajām bērnības takām Rīgā un Latvijas laukos, vēsta par kara okupācijām, tēva apcietināšanu un izsūtīšanu, par kara jukām un nejaušībām, gimenes sadalīšanu un frontes līnijas spiedienu, kara bēgḷiem nepārtraukti pārvietojoties tuvāk Rietumiem, prom no Sarkanās armijas. Turpinājumā vina stāsta par dz̄ivi kara sagrautajā Vācijā un bēgḷu nometnē Eslingenā, un ASV - kas ietver Latvijas mīlestību, amerikanizēšanās draudus, latviskās identitātes pārnešanu uz bērniem un vilšanos bērnu rīcībā un latviskuma izpratnē.

Latvija autores atmiṇās kḷūst aizvien skaistāka, gaišāka, saulaināka, bet nereālāka, nesasniedzamāka - kā Raiṇa Saulcerīte stikla

3 Judina, Dace (2016) Septini vakari, I; (2017) Gredzens, II; (2017) Kad klusums kliedz, III; (2018) Uzraksti man... vakar, IV. Rīga : Lauku avīze / Latvijas Mediji.

4 Barbins-Stahnke, Astrida (2015) How Long is Exile, I: The Song and Dance Festival of Free Latvians; (2016) How Long is Exile, II: Out of the Ruins of Germany; (2016) How Long is Exile, III: The Long Road Home. Bloomington, Ind. : Xlibris Publishing. 
kalnā. Taču trilogijas pēdējā daḷā š̄i Latvijas mīlestība daḷēji izplūst neveiklos un pāriplūstošos emocionāli tiešos un netiešos kontaktos un neracionālās saitēs ar Latviju, zemtekstā iekḷaujot visas aukstā kara politiskās peripetijas.

Lai gan romāns uzrakstīts trešajā personā, tātad par Mildu Bērziņu, tā pārdzīvojumu emocionalitāte lasītājam liek domāt, ka romāns uzrakstīts pirmajā personā un runā "es". Cik dziḷi pati autore saistīta ar emocionālo romāna vēstījumu, rāda arī valoda. Romāns uzrakstīts ang̣̣u valodā, it kā amerikāṇu publikai, taču varu droši apgalvot, ka amerikāṇu lasītāji to nevarēs saprast, neskatoties uz to, ka pirmajai romāna daḷai ir trīs skaidrojoši ievadi. Autore tekstā regulāri iemet pa kādam latviešu vārdam, tos netulkojot, un arī angḷu teksts ir vietām loti "latvisks" - rakstīts angḷ valodā, bet latviskā kodā. Amerikāṇu lasītājam romāns kḷūst vēl nepieejamāks ar daudzām izvērstajām latviešu literatūras analīzēm un metaforām.

Romāna nosaukums Cik gara ir trimda vai Cik ilgi ilgst trimda ir l̦oti ietilpīgs. Pirmajā acumirklī tas šķiet vai nu lineārs - cik ilgi, vai juridisks - trimdas laika un vietas definīcijas. Taču A. Stankes trimdas jēdziens ir daudz plašāks, tas ietver filozofisko jautājumu par "no Latvijas teritorijas atrauto latvietību". Cik ilgi tu svešumā vari pastāvēt kā latvietis, cik ilgi vari pretoties Amerikas melting pot (kausējamais katls - red.) videi, cik ilgi vari saglabāt valodu, un kas galu galā ir tā sauktā latvietība, kur un kā tā sākas un kur un kā tā beidzas. Un vai šî pirmskara "iekonservētā" latvietība ir saskaņojama/integrējama ar pēcpadomju Latvijas latvietību? A. Stankes romāns, no vienas puses, ir latvietības grēksūdze - vai tu esi darījis visu, lai sevi un savu vidi saglabātu Latvijai, no otras puses - viss romāns ir mīlestības dziesma Latvijai.

A. Stanke pieskaras arī kādai latviešu literatūrā maz aplūkotai tēmai, proti, kara invalīdiem - Latvijas (un ne jau tikai Latvijas) pēckara vēstures ḷoti būtiskai sastāvdaḷai. Vācijas bēglu nometņu ikdienas skatam piederēja jauni, skaisti, stalti, bet sakropḷoti vīrieši, kas karā bija zaudējuši kādu locekli vai acu gaismu. No vienas puses, viņi saņēma sabiedrības cieṇu kā kara varoṇi, no otras - viniiem bija grūti iekḷauties latviešu bēgḷu sabiedrības "normālajā" ikdienā, kurā cilvēki centās karu aizmirst, tikt tik tālu prom no Padomju Savienības okupācijas varas, cik vien iespējams, atrast normālu dzīves ikdienu. Šis bailes no Padomju Savienības varas pagarinātās rokas ${ }^{5}$ skaidri rāda, ka trimdas latviešiem karš nebija beidzies. Arī izceḷošana invalīdiem bija sarežǵīta, jo ieceḷotājvalstis gribēja iespējami efektīvu darbaspēku, nevis invalīdus. Invalīdi uz katra soḷa atgādināja par karu. Lai arī kā cilvēki grib aizbēgt un aizmirst karu, tas neizdodas, kara sekas ir pielipušas ikkatram, kas to piedzìvojis. Bēgḷu vēlmi aizmirst karu traucēja arī pastāvīgās gan pamatotās, gan $\mathrm{Pa}$ domju Savienības rosinātās nepamatotās kara noziegumu apsūdzības un tiesas.

Mildas dzīvē tieši viens bijušais karavīrs, kam ir viena roka, ieņem nozīmīgu vietu. Lai gan saderinājusies un salaulājusies ar citu, kam Milda vēlas būt uzticīga, no šī karavīra vina izjūt milzīgu vīrišḳīgu pievilkšanas spēku, viṇu vienlaikus mīl un ienīst.

A. Stankes romāns ir laikmetīgās vēstures, attiecību un identitātes romāns. Tas tieši atbilst G. Repšes uzaicinājumam, vienīgi laikmetīgā vēsture nav sameklēta bibliotēkās un arhīvos, tā ir autobiogrāfiska ${ }^{6}$. Pārtulkots latviski un vismaz uz pusi saīsināts, A. Stankes romāns labi iederētos un papildinātu G. Repšes romānu sēriju ar pilnīgi citu Latvijas vēstures posmu un skatîjumu.

Šeit vēlos analizēt nevis G. Repšes romānu sērijas un A. Stankes romāna literāro kvalitāti, bet gan romānu atbilstību nacionālās identitātes statusam un meklējumiem, mūsu laikmetīgās vēstures būtiskai sastāvdaļai. A. Stanke lasītāja uzmanību vērš uz nacionālās identitātes "dz̄ives jēgu" visu 1200 lappušu garumā, toties G. Repšes ierosinātajā romānu sērijā autori, izmantojot malā stāvošus un marginalizētus sabiedrības tēlus, vairāk vai mazāk "urbjas pa

5 Izsmel̦oša informācija par š̄is "Padomju Savienības varas pagarinātās rokas" darbību un stratēgiju atrodama pētījumā: Zalkalns, Lilita (2014) Back to the Motherland: Repatriation and Latvian Emigres 1955-1958. Stockholm : Stockholm University. Pieejams: http://su.diva-portal. org/smash/get/diva2:749334/FULLTEXT02.pdf (24.02.2019.).

6 A. Stanke pati stāstījusi draudzenei Brigitai Šilinai: "Tur nekas nav izdomāts, tikai sajaukts līdz nepazī̌sanai." 
savu nabu", pa savu es - uz G. Repšes norādītā laikmeta skatuviski stilizēto dekorāciju, nevis vēsturiskā laikmeta fona. Ar trim izṇēmumiem. Arno Jundze savā romānā Sarkanais dz̄̄vsudrabs lasītājus "izbīda" cauri 90. gadu apjukušajiem nacionālās identitātes meklējumiem. Māra Bērziņa varonis romānā Svina garša, pārstāvēdams lielu tālaika naivo, karam nesagatavoto jauno cilvēku dalı, Ērikas Marijas Remarka manierē tiek konfrontēts ar kara šausmu īstenību - pret svina lodēm nacionālā identitāte un nejaušības nav aizsargātas. Andra Akmentiņa romāns Skolotāji sniedz lasītājiem interesantu ieskatu, kā Padomju Savienības iekārtā nacionālā identitāte tiek noslēpta aizvien dziḷākā kabatā, to, laikam ejot, atvietojot ar laba un êtiska skolotāja profesionalitāti.

Bet kur pārējos "Repšes sērijas" romānos ir nacionālās identitātes jautājums? Ja romānos atveidotajos sabiedrības malā stāvošos varoņos ir atspogulota autoru nacionālā identitāte, ja šis ir mūsu kultūras un vēstures apziņas mantojums, mūsu skats uz neseno vēsturi, nudien jājautā: kāda loma pie mums tad ir vēsturiskās ētikas un izpratnes apziņai? Kas mūsu sabiedrībā ir aizgājis greizi, ka spoži rakstnieki interpretē G. Repšes aicinājumu tik sakropḷotu tēlu sakroplototas vides attēlā? Vai patiešām tā ir mūsu 20. gadsimta latviskā identitāte, ar ko gribam lepoties Latvijas simtgadē un ko gribam nodot tālāk saviem pēctečiem kā Latvijas vīziju ar skatu uz nākotni? Kas ir noticis, ka romānu tekstos ir zudusi Latvijas, savas valsts, mīlestība? Kas ir nonāvējis Latvijas mīlestību? Padomju vide, audzināšana, tas, ka Padomju Savienība falsificēja pagātni? Varbūt tas ir nevis Latvijas mīlestības, bet latviskās identitātes jautājums? Vai autori tādēḷ slēpj savu nacionālo identitāti aiz kaut kur izraktiem margināliem pagātnes notikumiem tāpēc, ka viniiem nav šīs identitātes?

Nacionālās identitātes jautājums nav atrisināms, rotaḷājoties ar vēsturi vai postmodernisma saukḷos iegremdētu vēstures romānu. Tas nav tikai divu vārdu salikums, kas labi noder, pieprasot atbalstu projektiem, tā ir atbild̄̄ba pret savu valsti, atbildība par vēsturisko un pilsonisko apziņu, par piederību savai valstij, ko A. Stanke rāda visa sava garā romāna garumā, neskatoties uz to, ka sava mūža lielāko daļu nodzīvojusi svešumā, svešas kultūras vidē ASV un ka romāns uzrakstīts angḷu valodā. 